\title{
Access Barriers to Health Services Perceived by People Living With HIV and Their Families
}

\author{
Lemy Bran-Piedrahita ${ }^{1}$, Sergio Gómez-Molina ${ }^{1}$, Alejandro Valencia-Arias ${ }^{2}$, Rosa Vélez-Holguín ${ }^{3}$, Lucía \\ Palacios-Moya ${ }^{4}$, Yesenia Acevedo-Correa ${ }^{1} \&$ Claudia Arias-Arciniegas ${ }^{1}$ \\ ${ }^{1}$ Coordinación General de Investigaciones, Fundación Universitaria Católica del Norte, Medellín, Colombia \\ ${ }^{2}$ Facultad de Ciencias Económicas y Administrativas, Instituto Tecnológico Metropolitano, Medellín, Colombia \\ ${ }^{3}$ Dirección Académica, Fundación Universitaria Católica del Norte, Medellín, Colombia \\ ${ }^{4}$ Coordinación de Investigaciones, Institución Universitaria Escolme, Medellín, Colombia \\ Correspondence: Lemy Bran-Piedrahita, Coordinación General de Investigaciones, Fundación Universitaria \\ Católica del Norte, Medellín, Antioquia 050012, Colombia. Tel: (57+4)-318-209-6296. E-mail: \\ lbpiedrahita@ucn.edu.co
}

Received: October 4, 2017 Accepted: February 1, 2018 Online Published: February 9, 2018

doi:10.5539/gjhs.v10n3p54 URL: https://doi.org/10.5539/gjhs.v10n3p54

\begin{abstract}
Introducction: The Human Immunodeficiency Virus (HIV) is a retrovirus that destroys the body's T cells. Its advanced stage is the Acquired Immune Deficiency Syndrome (AIDS), since its onset, it has been extensively studied because of an associated burden of morbidity and also to understand the access barriers to diagnostic tests and the required treatment. Objective: To understand the barriers to access health services as perceived by adults living with HIV and their families in the city of Medellín (Colombia).
\end{abstract}

Methodology: A qualitative investigation by using historical-hermeneutical approach was carried out, involving 23 participants (seropositive patients and their relatives). The information was collected through semi-structured interviews, later codified and analyzed based on Strauss and Corbin's Grounded Theory.

Results: In this study, the access barriers to health services as perceived by adults living with HIV and their families are represented in administrative constraints, affecting economic and interpersonal relationships as well as social nature that materialize the impact of the social stigmas created around the virus on the mental health of seropositive person and their closest affective environment.

Conclusion: The stigma surrounding HIV leads seropositive people and their families to perceive it as a barrier to accessing cultural services, which demands greater intervention efforts by health authorities than other types of barriers in health systems.

Keywords: HIV, acquired immune deficiency syndrome, grounded theory, health system, health services, social stigma

\section{Introduction}

The first cases of Human Immunodeficiency Virus (HIV) were detected in the cities of New York, Los Angeles and San Francisco in the United States in the late 1970s. These were initially reported in homosexual men but quickly began to be found in other population groups such as users of drug injections, Haitians, sex workers and infected women' chidren. This led to social responses toward the epidemic that were associated with fear and ignorance, which has undoubtedly marked a milestone for the virus' stigma (Bermudez et al., 2015).

According to the Joint United Nations Program on HIV/AIDS (UNAIDS), from the first cases reported in 1981 until the end of 2013, more than 39 million people died as a result of medical complications associated with the virus. In Latin America and the Caribbean, the epidemic behavior has varied, not only in terms of the population groups most exposed to contagion, but also because in comparison with other regions such as North Africa, the Middle East and Central Asia, the representativeness of the virus is low (Wu et al., 2016; Barros, 2015). Nevertheless, this does not stop generating a series of challenges for health systems.

These challenges are: reversing the increase of infection, which has been the goal since the definition of the Millennium Development Goals, ensuring the provision of antiretroviral therapy (ART) and therapeutic adherence 
to it, which is manifested in the scientific community to study these aspects in depth; opposing the stigma associated with the virus, fed by the social representations built around the origin of the disease and guaranteeing integral access to health services, mitigating the barriers that may arise (Cabrera, García, \& Castell, 2016; Bermúdez et al, 2015; Almanza \& Flores, 2012; Laria \& Rodríguez, 2013).

However, the barriers to access health services for those living with the virus still persist. Different studies show the difficulties in obtaining services on time like the Elisa test. These late diagnoses thus lead to the aggravation of the infection in those who present it, and the shortcomings of the health structures of countries. In the Colombian context, these are evidenced by constant bureaucratic procedures, denials of treatments, and the constant use of guardianship actions as a mechanism for seeking protection of the fundamental rights, particulary to health. Also make vulnerable groups such as women in poverty face problems in accessing the system's offer. Additionally, the impact of HIV-related stigma also affects the access to health services (Bermúdez et al., 2015; Vega et al., 2015).

Therefore, an investigation was proposed in order to understand the perceived access barriers to health services by adults with HIV and their families in the city of Medellín, by the year 2016. The participants included the relatives of the patients, because although the existing literature has been interested in studying access barriers, few have focused on including the family nucleus, which often are the emotional and economic support of those who have the virus.

\section{Methodology}

A qualitative research with a historical-hermeneutical approach was carried out during one year. Its objective was to understand the access barriers to health services as perceived by adults living with HIV and their relatives in the city of Medellín (Colombia), by the year 2016. A total of 23 key people participated. These were contacted through the RASA, SIFUTURO and the SanVicente Hospital Foundations of the city of Medellín. It should be noted that, by the date of the study, were registered in the city according to Antioquia's Department of Health (Colombia), maximum health authority of the locality, 1174 cases with a rate of 47.2 infected per 100,000 habitants (Antioquia's Department of Health, 2017).

The selection was made by a theoretical sampling. Although the researchers do not pursue statistical generalizations, given the qualitative nature of the study, the participants are expected to reflect qualitatively the studied phenomenon. Thus, for this case, the greatest possible diversity was sought, based on variables such as age, gender, affiliation with the health system and socioeconomic status. Other aspects such as the distance between the patient's home and the place of delivering health services, as well as information regarding who covers the costs of care for the participants were not considered in the selection of them, since finally the intention of the study was to be able to reveal whether this type of access barriers that are perceived by the target population of this research.

In addition, inclusion criteria were: being of legal age, being diagnosed with HIV or being related to someone with this condition, and receiving health care in the city. As a criterion of exclusion, the suffering of severe mental disorders that prevented voluntary and conscious participation in the research was taken into account. Likewise, as ethical considerations guaranteeing the participation of informants, elements of the Declaration of Helsinki were incorporated. It establishes the obligatory nature of any study involving human beings to submit research projects to an ethics committee and to have as guiding principles beneficence, justice and autonomy, also known as bases of bioethics. In addition, the guidelines of Resolution 8430 of 1993 of the Colombian Ministry of Health were followed. It establishes the scientific procedures to be considered in order to guarantee the protection of the participating subjects.

To collect the information, semi-structured interviews were used in depth, in order to allow an open dialogue with the participants. In order to validate the clarity of the built instrument, a pilot test was done with 4 of the participants, which allowed to improve it and guarantee understanding by the interviewees. These interviews were conducted in Spanish language on an individual basis to each participant, applied directly by the authors, with infected participants and their families separately, in order to avoid biases in their responses.

The interviews were transcribed and codified, taking as referent the Grounded Theory of Anselm Strauss and Juliet Corbin, whicdh within this framework, codification is a process through which the narratives of the participants are fragmented to identify the richness of the data, allowing the understanding of the studied phenomenon.

This theory contemplates three stages of codification: during the first one, called "open", some so-called descriptive categories arise; during the second, known as "axial", other analytical titles arise through associations between the first emergent categories; and the third, "selective", leads to the emergence of the interpretive categories, which allow to determine the core axis to theorize the studied phenomenon. However, due to budgetary issues in the execution of the research, it only reaches the generation of analytical categories, which are presented 
as a result in the present manuscript.

\section{Results}

The research, as mentioned in the methodological section, had a total of 23 participants, 15 of these were women and 8 men, ranging in age from 26 to 55 years old. With regard to their marital status, 16 of them were single, 3 married and 4 lived in free union. In addition, it is worth noting that the 10 of these belonged to socioeconomic status 1 (corresponding to the lowest level in the Colombian classification which variates in a scale from 1 to 6), 13 belonged to 2, 3 and 4 status and only 2 people in the last two status, which reveals an important characteristic in the participants of this studiy and is their belonging to the lower-middle classes of the city.

In light of key informants in this study, access barriers perceived by adults living with HIV and their families in the city of Medellin are associated with administrative and social constraints. Thus, when participants referred to the impact of administrative barriers on the economic situation of those living with HIV and their families, they revealed that the persistent constraints in the Colombian health system lead HIV positive individuals and their families to constantly go to health institutions to demand medication, to process orders for procedures and so on, which involves incurring a series of additional expenses that affect the home economy, as is expressed by different informants:

"Finding so many administrative obstacles implies a greater expense for the family, because there are administrative obstacles that require reprocessing of where we have to spend more money and time".

"Going two and three times a week to the Healthcare Providers Entities requires tickets and having to eat something there, and there is no money for that".

Likewise, participants report that their finances are affected not only by expenses associated with mobility in order to carry out the different procedures demanded by the Colombian health system, but also by spending money on drugs that are not delivered on time and that are necessary to ensure the continuity of treatment, as expressed by some of them:

"Many times they do not generate the orders on time or they give us a very late appointment, so we have to take money from our own pockets to pay for it, which affects the economy a lot".

"The drugs and the appointments are very expensive, this makes the economy worse".

Consequently, the participants referred to the effects of administrative barriers on their family relationships, since the constant procedures to which they must submit, such as standing in long lines and time lost in order to authorize medical orders and other processes, lead them to become easely irritated. Homes are the stage where these changes in behaviors are most perceived. Hence, there are constant tensions that deteriorate the relationship between the HIV-positive individual and his/her environment. This was expressed by different informants:

"The drugs are very expensive, you have to stand in endless lines to be able to claim them and sometimes they do not deliver anything. Then, the moods change and I argue with my family and friends, and that generates a lot of stress".

"When the patient stands in lines to demand orders, he/she is stressed out by long waiting, which generates controversy within the family”.

Finally, the interviewees refer to not only administrative barriers in the health system, but also social ones. Among them, it was possible to identify the impact of the stigma created around HIV on the mental health of infected people and their families. The fact that the first reported cases of the disease have occurred in specific population groups like homosexuals, sex workers and intravenous drug users has led to a marked stigma that, even after more than thirty years of the first infected, continues to represent a psychological, social and cultural burden not only for those who are HIV positive, but also for their relatives, as has been exposed throughout this manuscript, are a fundamental support for those living with HIV.

In this sense, the participants expressed a series of statements that highlight the impact of said stigma and other representations of the virus on their mental health, as reflected in the following fragments:

"When I was recently diagnosed it was too hard. I did not want anything because HIV is a taboo, because people from the system reject it”.

"The disease affects us all in the family, because one must face discrimination just because one has the disease”.

"We have had to go to the psychologist many times because he feels rejected. He has not been able to get a partner because he thinks his illness has already stopped his life”. 
Thus, in this study, the access barriers to health services as perceived by adults living with HIV and their families are represented in administrative constraints affecting economic and interpersonal relationships as well as others of a social nature that materialize in the impact of the stigmas created around the virus on the mental health of seropositive subjects and their closest affective environment.

\section{Discussion}

Accessibility and acceptability become recurrent factors of investigation, being conceived as the two great barriers in the full use of health services (Correa \& Valencia, 2016). In addition, their study is more frequent in populations considered to be vulnerable - such as older adults, indigenous people, migrants, children, women and patients with chronic and transmissible diseases - as they already pose a series of challenges for health systems (Hirmas et al., 2013; Juárez et al., 2014; Agost \& Martín, 2012; Contel, Muntané, \& Camp, 2012; De Oliveira et al., 2013).

Thus, communicable diseases such as HIV have become a topic of interest not only because of the impact it has generated for global public health, but also because of the barriers faced by people living with the virus in order to access services of health and prevention of such disease. Although most studies have focused on issues related to antiretroviral treatment (ART) because it is a collective goal to ensure coverage of the entire infected population, without ignoring that such access is conditional on each context (Olivera et al., 2012; Arrivillaga \& Salcedo, 2012; Sarang, Rhodes, \& Sheon, 2013).

In this regard, the research carried out makes clear three important elements of barriers to accessing health services for people living with HIV, according to the perspectives of users living with HIV and their families. The first element concerns the impact of administrative constraints on the economic situation of HIV-positive individuals and their families.

Some studies on accessibility to health services in the Colombian context, such as that carried out by Vargas \& Molina (2009), reveal the existence of administrative barriers in the Gerenal System of Health Social Security (SGSSS by the aronym in spanish), where patient insurance does not guarantee full access to the required services, triggering constant actions of guardianship to enforce health rights and increasing out-of-pocket costs for users; which is consistent with the findings in the first category of research presented in this manuscript. In addition, the results of Lopera, Martínez, \& Ray (2011) reflect in the framework of the SGSSS, the interruption of treatment by users due to the shortcomings of the Health Service Provider Institutions. In addition, to a series of other factors that increase the health costs assumed by patients, which in view of the study presented here, is consolidated as an administrative barrier to access to services.

Now, the second element that was highlighted in the study has to do with the effect of administrative barriers on family relations. In this particular finding, it is important to note that the consulted literature shows the perceptions of users and their relationship dynamics only from a healthcare perspective, this is the case of the research carried out by Marín \& Chávez (2013), who relate the incidence of administrative barriers in emergency care and the way in which the relationship between the patient, family and healthcare professionals can be hindered (Asela-Molina, 2015). Therefore, the contrasting of this category with existing information from other studies reveals the gap in the field of knowledge, so it is pertinent to encourage the different researchers in areas related to public health and social sciences to investigate in depth the effects that barriers to access to health services can have on family interactions.

Finally, the third key element found in this research has to do with the impact of the stigma created around the virus on the mental health of people living with HIV and their families. Various approaches have been taken in this category, both in the field of public health and social sciences. Some approaches to this topic have been developed by researchers such as Wohl et al (2012), who analyzed aspects such as HIV stigma, depression, stress and social support in Latino and African American men diagnosed with HIV, which supports the results of research presented in this manuscript, reflecting the association between HIV stigma and mental health of those infected.

\section{Conclusions}

The presence of access barriers to health services has been widely debated, particularly in those countries where the guarantee to the integral attention of the population by the different actors of the health system becomes more complex due to their socioeconomic characteristics. This is the case of Latin American countries like Colombia, where the gap between riches and poors is undoubtedly a key aspect for understanding the barriers that persist in the system.

These become more complex for those groups whose social, economic, cultural, demographic and even epidemiological characteristics acquire the connotation of vulnerable groups. One of the most affected groups are those living with chronic and transmissible diseases, and for the particular case of the results exposed in this 
manuscript, people living with HIV and their families.

In this sense, in view of the results found in this research, it can be inferred that the existence of administrative barriers in the Colombian health system negatively impacts the economic situation of those living with the virus and their families, due to the constant procedures that people must carry out to claim medicines, request medical appointments, among others. In addition, this type of barriers leads to altering the relationship between the infected individual and his or her family, since the stress load generated by the constant procedures to which they are exposed is poorly channelled in the home.

Likewise, according to the findings of the study, it is clear what other studies have already addressed, in relation to the impact that the stigma around the virus has on the mental health of HIV-positive people and their families. This is a cultural barrier that, according to the authors, demands greater efforts on the part of health authorities, since they require joint action not only from the actors of the health system, but also from the community in general.

In addition, one of the possible strategies to improve coverage and care for patients with transmisible diseases is telemedicine (Benjumea, Villa, \& Valencia, 2016) but this should be based on a national strategy that strengthens the link with patients who cannot travel to health care centres. This requires technological adoption studies to identify the factors that would allow a proper implementation of the strategy (Valencia, Gonzalez, \& Castañeda, 2016; Bermudez, Chalela, J.Valencia, \& A. Valencia, 2017).

\section{Acknowledgements}

We the authors wish to express our gratitude towards all those participating in this study, who ultimately gave meaning to the results presented in this research.

\section{Competing Interests Statement}

The authors declare that they have no competing or potential conflicts of interest.

\section{References}

Agost Felip, M., \& Martín, L. (2012). Approach to the role of the social exclusion processes and their relation with health. Revista Cubana de Salud Pública, http://dx.doi.org/10.1590/S0864-34662012000100012

Almanza, A., \& Flores, F. (2012). Resisting discrimination: family narratives about HIV infection. An exploratory study. Psicología $y \quad$ Salud., 22(2), 173-84. $\quad$ Retrieved from http://revistas.uv.mx/index.php/psicysalud/article/view/531

Antioquia's departament of Health. (2017). Events of interest of public health by subregions and municipalities. $\begin{array}{lllll}\text { Antioquia } & 2007 & - & 2016 . & \text { Retrieved }\end{array}$ http://www.dssa.gov.co/index.php/estadisticas/eventos-en-salud-publica/item/71-eventos-de-interes-en-salu d-publica-por-subregiones-y-municipios-antioquia-2007-2016 (consulted 2017 jan 3).

Arraes, C. O., Palos, M. A., Barbosa, M. A., Teles, S. A., Souza, M. M., \& Matos, M. A. (2013). Masculinity, vulnerability and prevention of std/hiv/aids among male adolescents: social representations in a land reform settlement. Rev Lat Am Enfermagem, 21(6), 1266-1273. http://dx.doi.org/10.1590/0104-1169.3059.2363

Arrivillaga, M., \& Salcedo, J. (2012). Intersecciones entre posición socioeconómica, mecanismos psicológicos y comportamientos de adherencia en VIH/SIDA: aproximación cualitativa desde la perspectiva del curso de vida. Pensamiento Psicológico, 10(2), 49-64. Retrieved from http://www.scielo.org.co/scielo.php?script=sci_arttext\&pid=S1657-89612012000200006

Asela-Molina, J. E. (2015). La descentralización en Colombia, ¿realidad o espejismo? Consideraciones sobre la actualidad del proceso. Revista CEA, 1(1), 65-74. https://doi.org/10.22430/24223182.63

Barros, E. (2015). Evaluación de las pruebas confirmatorias disponibles en Colombia para el diagnóstico de la infección por VIH-1: Western blot e inmunoblots de peptidos sintéticos y proteinas recombinantes. (Unpublished master dissertation), Universidad Nacional de Colombia, Bogota, Colombia.

Benjumea-Arias, M. L., Villa-Enciso, E. M., \& Valencia-Arias, J. (2016). Beneficios e impactos del teletrabajo en el talento humano. Resultados desde una revisión de literatura. Revista CEA, 2(4), 59-73. https://doi.org/10.22430/24223182.172

Bermudez, J., Chalela, S., Valencia, J., \& Valencia, A. (2017). Research Trends in the Study of ICT Based Learning Communities: A Bibliometric Analysis. EURASIA Journal of Mathematics, Science and Technology Education, 13(5), 1539-1562. 
Bermúdez, V., Bran, L., Palacios, L., \& Posada, I. (2015). Influence of HIV related stigma on health care access. Revista Salud Pública de México. 57(3), 252-59.

Cabrera, P., García, A., \& Castell, P. (2016). The Millenium Development Goals and the Sustainable Development Goals in the Cuban public health. Revista Cubana de Salud Pública. 42(4), 577-584. Retrieved from http://scielo.sld.cu/pdf/rcsp/v42n4/spu08416.pdf

Contel, C., Muntané, B., \& Camp, L. (2012). Care of the chronic patient in a complex situation: the challenge of building an integrated care scenario. Atención Primaria. 44(2), 107-13. https://doi.org/10.1016/j.aprim.2011.01.013

Correa, A., \& Valencia, A. (2016). Social Responsibility and Ethics in Medical Health. Ratio Juris, 11(22), 73-89.

Hirmas, A. M., Poffald, A. L., Aguilera, S. X., Delgado, B. I., \& Vega, M. J. (2013). [health care access barriers and facilitators: a qualitative systematic review]. Revista panamericana de salud pública $=$ Pan American journal of public health, 33(3), 223-9. Retrieved from https://www.scielosp.org/scielo.php?script=sci_arttext\&pid=S1020-49892013000300009

Juã, r. C., Mã, r. M., Salgado, d. S. N., Pelcastre-Villafuerte, B. E., Ruelas-GonzÃ lez, M. G., \& Reyes-Morales, H. (2014). [health inequality among vulnerable groups in mexico: older adults, indigenous people, and migrants]. Rev Panam Salud Publica, 35(4), 284-90. Retrieved from https://scielosp.org/pdf/rpsp/v35n4/08.pdf

Laria, S \& Rodríguez, E. (2013). Assessing the comprehensive care given to HIV/AIDS people in Cuba. Revista Cubana de Medicina General Integral. 29(4), 336-43. Retrieved from http://scielo.sld.cu/pdf/mgi/v29n4/mgi07413.pdf

Lopera, M., Martínez, J., \& Ray, T. (2011). Access of People with HIV to the Colombian Healthcare System and its Related Costs from an Individual and Family Perspective, Bogotá, 2010. Gerencia y Políticas de Salud. 10(20), 81-96. Retrieved from http://www.scielo.org.co/pdf/rgps/v10n20/v10n20a06.pdf

Marín, Y., \& Chávez, B. (2013). Inconsistencies in the affiliation of the Colombian health system: an administrative barrier to the comprehensive treatment of medical emergencies. Rev Fac Nac Salud Pública, 32(1), 62-70.

Olivera, J., De la Rúa, E., Gracia, A., \& Ramírez, A. (2012). Risk perception of nurses in patient care living with HIV-AIDS. Revista Cubana de Enfermería. 28(4), 521-31. Retrieved from http://scielo.sld.cu/pdf/enf/v28n4/enf08412.pdf

Sarang, A., Rhodes, T., \& Sheon, N. (2013). Systemic barriers accessing HIV treatment among people who inject drugs in Russia: a qualitative study. Health policy and planning. 28(7), 681-91. https://doi.org/10.1093/heapol/czs107

Valencia, A., Gonzalez, G., \& Castañeda, M. (2016). Structural equation model for studying the mobile-learning acceptance. IEEE Latin America Transactions, 14(4), 1988-1992. https://doi.org/10.1109/TLA.2016.7483544

Vargas, J., \& Molina, G. (2009). Access to health services in six Colombian cities: limitations and consequences. Rev Fac Nac Salud Pública; 27(2), 121-30.

Vega, P., Araya, A., Urrutia, M., Carrasco, P., \& Rubio, M. (2015). Uncovering the perceived barriers of users to Access to test for HIV Elisa Test. Ciencia $y$ Enfermería, 21(2), 77-85. http://dx.doi.org/10.4067/S0717-95532015000200008

Wohl, A. R., Galvan, F. H., Carlos, J. A., Myers, H. F., Garland, W., Witt, M. D., ... George, S. (2013). A comparison of msm stigma, hiv stigma and depression in hiv-positive latino and african american men who have sex with men (msm). Aids Behav, 17(4), 1454-1464. http://dx.doi.org/10.1007/s10461-012-0385-9

Wu, E., Galaz, M. I., Larrañaga, C., Chávez, A. et al. (2016). HIV/AIDS infection in children and adolescents: Chilean cohort 1987-2014. Revista Chilena de Infectología, 33(1), 11-9. http://dx.doi.org/10.4067/S0716-10182016000700002

\section{Copyrights}

Copyright for this article is retained by the author(s), with first publication rights granted to the journal.

This is an open-access article distributed under the terms and conditions of the Creative Commons Attribution license (http://creativecommons.org/licenses/by/4.0/). 